\title{
EFFECTIVITY ANTIBACTERIAL ZINC OXIDE EUGENOL WITH ZINC OXIDE PROPOLIS FOR ENDODONTIC TREATMENT IN PRIMARY TEETH
}

\author{
Erwid Fatchur Rahman* ,Sandy Christiono ${ }^{* *}$
}

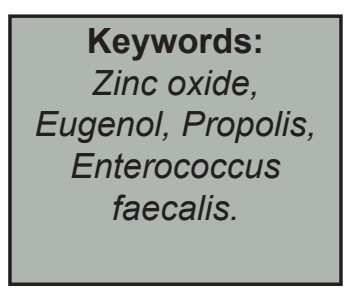

\section{ABSTRACT}

Background: Enterococcus faecalis is generally found on the failure of root canal treatments. Zinc oxide propolis is believed to have an antibacterial effect on that bacteria. This research aimed to compare bacteriostatic effect of zinc oxide eugenol (ZOE) and zinc oxide propolis (ZOP) as the sealer materials of root canal.

Method: This was an experimental research with post-test only control group design with two different groups (ZOE and ZOP). Culture of Enterococcus faecalis bacteria was smeared on Blood Agar Plate media with six times replication per group and kept inside incubator for 24 hours. The result was obtained from the inhibition zone formed around the pasta.

Result: The average result of ZOE and ZOP was $27.7 \mathrm{~mm}$ and $13.45 \mathrm{~mm}$ respectively. Normality test using Shapiro-Wilks showed that data was normal $(p>0.05)$. Then, the data was analysed using Independent Samples T-test. The result showed that there was different inhibition zone between ZOE group and ZOP group $(p<0.05)$.

Conclusion: Based on the result, it can be concluded that ZOP has lower antibacterial effectiveness of the Enterococcus faecalis than ZOE.

\section{INTRODUCTION}

Elimination microorganism from infected root canals are major focus in the root canal treatment mainly primary teeth, presence of bacteria play an important role in the pathogenesis of pulp and success of endodontic treatment. ${ }^{1}$ the bacteria can survive in the root canals is Enterococcus class of anaerobic bacteria and Enterococcus one of part infection of endodontic treatment. Enterococcus facealis is resistant bacteria in root canal and can survive long periods without additional nutrient. 1,2 Enterococcus faecalis is most often cause of the infection at the root canal treatment. Retreatment usually fail because of failure to clean or kill the bacteria on the initial treatment. ${ }^{2}$

Endodontic treatment is one of type to maintain teeth in order to continue the function. Stage of endodontic treatment are preparation, disinfection and obturation of root canal. The successful of endodontic treatment requires proper preparation and obturation the root canal, especially on the apical third. A number of $60 \%$ of treatment failures caused by poor of obturation in the root canal. ${ }^{3}$

Since 1930, zinc oxide eugenol has been the material of choice. But it lacks in slow resorption, periapical tissue irritation, necrosis of bone and cementum and changes the path of eruption of permanent teeth. ${ }^{4}$ Zinc oxide eugenol is also cytotoxic to the cell and connective tissue. This is caused by release of eugenol because of hydrolysis on the surface of the cement. ${ }^{5}$ It is necessary to develop an antimicrobial material that does not irritate the periapical tissues and cause inflammation.

Propolis contains at least 38 types of flavonoids, among others: galagin, kaemfenol, quercentin, pinocembrin, pinostrobin, and pi-

${ }^{*}$ Department of Bedah mulut dan Maksilofasial, Faculty of Dentistry, Sultan Agung Islamic University, Semarang - Indonesia, **Department of Pediatric Dentistry, Faculty of Dentistry, Sultan Agung Islamic University, Semarang Indonesia

Korespondensi: erwid@unissula.ac.id 
nobasksin. Propolis has been known to have the ability as an antimicrobial, anti-inflammatory, anaesthetic, systolic, and cariostatic. Flavonoids can inhibit the growth of microorganisms because it can form complexes with proteins through hydrogen bonding. Polyphenols and phenol works as an antibacterial by denaturation protein and cell membrane plasma damage. ${ }^{6}$ A scientific study found that propolis inhibited the activity of some Streptococcus bacteria cause dental caries. ${ }^{7}$ Another study compared the antimicrobial of propolis, sodium hypochlorite and saline as irrigation materials intracanal. Bacterial samples take immediately post-opening of the root canal. These results indicate that propolis has antimicrobial activity similar to sodium hypochlorite. ${ }^{8}$ The results of another study entitled "Effect of Propolis on Human fibroblasts from the pulp and periodontal ligaments" showed that propolis with antibacterial, antifungal, antiviral, and its ability to enhance immune response, it is also possible to use as a replacement appropriate for endodontic intracanal because of lower cytotoxicity. ${ }^{9}$ The purpose of this study was to determine the antibacterial effectivity between zinc oxide eugenol with zinc oxide propolis as the endodontic treatment in the primary teeth in inhibiting the growth of bacteria Enterococcus faecalis in vitro.

\section{MATERIALS AND METHODS}

The type of this research was experimental. The study design was post-test only control group design. Samples were taken by the bacterium Enterococcus faecalis sensitivity Mc Farland standard. The materials used are zinc oxide eugenol and zinc oxide propolis, zinc oxide is made from zinc oxide powder manipulated with liquid. Propolis powder $2 \mathrm{~g}$ is dilut- ed with distilled water up to $10 \mathrm{ml}$, this solution were added to zinc oxide powder to make zinc oxide propolis. For medium used Blood Plate, Brain Heart Infusion (HIB), $0.9 \% \mathrm{NaCl}$ solution, sterile distilled water, alcohol $70 \%$. Equipment used in this study are: measuring pipette, light methylated, Ose sterile, Test tube, test tube racks, Propipet, cup dishes, autoclave, incubator, sliding caliper, cotton sterile, pinset, ruler, glass Beaker, cement spatula, glass slab.

Petri dishes, test tubes, sterilised by dry heating. Heating is carried out at a temperature of $160^{\circ} \mathrm{C}-180^{\circ} \mathrm{C}$ for $1.5-2$ hours. Tools which cannot be dry-heated such as pipettes and media, sterilised using by autoclave at a temperature of $120^{\circ} \mathrm{C}$ at $2 \mathrm{~atm}$ for 20 minutes. The tools to be used must be awaited prior to reach room temperature and dry. Pasta is made by manipulating the test of zinc oxide eugenol with 4:1 ratio of powder and liquid on the glass slab with a spatula cement, zinc oxide as well as propolis. Then making the bacteria Enterococcus faecalis suspension by bacterial culture was taken 1-2 ose Enterococcus faecalis aged 18-24 hours. Enter into a tube containing liquid medium Brain Hearth Infusion (HIB), and then incubated at $37^{\circ}$ for 24 hours then suspended in $0.9 \% \mathrm{NaCl}$ solution according to standard sensitivity Mc Farland III containing 9 x 108 bacteria/ $/ \mathrm{ml}^{2}$ germs .

Core test performed by a sterile cotton stick is inserted into the bacterial suspension Enterococcus faecalis that has been made, cotton stick was taken and razed to the Blood To Plate. Incubation at $37^{\circ} \mathrm{C}$ for 24 hours. Zinc oxide propolis, zinc oxide eugenol and sterile distilled water that has been placed on the surface of the media made Blood To Plate. Then put in petri dishes were incubated at a temperature incubator to $37^{\circ} \mathrm{C}$ for 24 hours. After incubation, the Petridish was observed the 
barrier zone formed around the paper discs. If the barrier zone is formed, take the measurement zone diameter size of the barriers by using sliding calliper. Resistance zone is measured from edge to edge past the paper discs. Experiments carried out one time and the replication six times.

\section{RESULTS}

The research was done by in vitro tests on bacterial growth media. Antibacterial effectiveness is shown by the formation of inhibition zones around the pasta test. The results antibacterial test of the effectiveness of zinc oxide eugenol and zinc oxide propolis in inhibiting the growth of Enterococcus faecalis in vitro are presented in table 1.
Inhibition zone showed the antibacterial effectiveness of zinc oxide eugenol and zinc oxide propolis against Enterococcus faecalis. In both groups the mean inhibition zone formed on the zinc oxide and zinc oxide eugenol propolis is $27.7 \mathrm{~mm}$ and $13.45 \mathrm{~mm}$.

The analysis showed that all groups had $p$ values $>0.05$ so that the data was distributed normally. After knowing the distribution of normal data, the homogeneity was tested. It showed that the zinc oxide eugenol antibacterial stronger than zinc oxide propolis (27.7333> 13.4500).

The test results showed that homogenity of $0.066(p>0.05)$ the data variance homogeneous. Therefore, because the data are normally distributed and homogeneous, parametric test requirements are met. Sig results Table 1.The results of the diameter of inhibition zone cause by zinc oxide eugenol and zinc oxide propolis on the growth of Enterococcus faecalis.

\begin{tabular}{ccc}
\hline Sample & \multicolumn{2}{c}{ Inhibition zone diameter $(\mathrm{mm})$} \\
\cline { 2 - 3 } & Zinc Oksida Eugenol & Zinc Oksida Propolis \\
\hline 1 & 32 & 13,1 \\
2 & 27,8 & 12,4 \\
4 & 22,5 & 13,4 \\
5 & 26,3 & 12,7 \\
6 & 30,9 & 14,7 \\
\hline Mean & 26,9 & 14,4 \\
\hline
\end{tabular}

Tabel 2. Normality test

\begin{tabular}{lc}
\hline Group & Sig. \\
\hline Zinc Oksida Eugenol & 0,806 \\
Zinc Oksida Propolis & 0,532
\end{tabular}


Tabel 3. T Test Independent Samples

\begin{tabular}{clll}
\hline group & p-value & Significancy & \\
\hline E. faecalis & ZOE & 0,000 & significant \\
& ZOP & & \\
\hline
\end{tabular}

showed a mean value of 0.000 and $0.000 p$ $<0.05$ then there is a significant difference in the data.

\section{DISCUSSION}

The result of independent statistical T-test, the mean inhibition zone diameter zinc oxide produced by propolis has a value $p<0.05$. This suggests that the resistance provided by the zinc oxide propolis statistically significant. However, effectiveness is still weaker than zinc oxide eugenol. The results of research that the inhibitory zone diameter zinc oxide eugenol is greater than the inhibition zone diameter zinc oxide propolis bacteria against bacteria enterococcus faecalis.

The ability of zinc oxide propolis mainly generated from the major chemical constituents of propolis is flavonoids. Flavonoids have many health-giving properties such as antiviral, antimicrobial, anti-inflammatory and antiallergic. ${ }^{10}$ In the research that was done showed that zinc oxide propolis could inhibit the growth of the bacteria Enterococcus faecalis, it is same with previous research that flavonoids in propolis may inhibit the growth of microorganisms because it can form complexes with proteins through hydrogen bonding. Polyphenols and phenol work as an antibacterial protein damage the cells and plasma membrane. ${ }^{6}$ Protein denaturation is the destruction of protein tertiary structure. Proteins present in the form of three-dimensional folds, which are determined by intramolecular disulfide bond and a covalent bond such as bond nonkovalen ionic, hydrophobic, hydrogen. This form is called the tertiary structure of proteins; are easily distracted by some chemical or physical agents, causing the protein to be not working. While the cell membrane works as a selective barrier, allowing some of the solute to pass through and hold other substances. Substances that are assembled on the cell surface can alter the physical and chemical properties of the membrane, the membrane prevents the normal functioning so that it will kill or inhibit the cell. ${ }^{11}$ Research conducted by Awawdeh et al, 2009, propolis as an intracanal medicament proven effective to eliminate Enterococcus faecalis. ${ }^{12}$

Eugenol is one of the phenol derivatives. The working of eugenol is similar to phenol itself. Damage to the structure of proteins by a number of physical and chemical elements can lead to death cell. These substances are concentrated on the cell surface may alter the physical and chemical properties of the cell wall, as well as blocking the normal function of the cell wall as a selective barrier and thus can lead to bacterial cell death. ${ }^{11}$ Appropriate in a previous study showed that use essential oils contain essential oils from leaves beluntas contain benzyl alcohol, benzyl acetate, eugenol and linolol. ${ }^{13}$

\section{CONCLUSION}

From these studies, we can conclude that there is a difference between the antibacterial effectiveness of zinc oxide eugenol and zinc 
oxide propolis as an ingredient Siler root canal treatment on primary teeth to inhibiting the growth of bacteria Enterococcus faecalis in vitro in which zinc oxide eugenol has a greater effect.

\section{REFERENCES}

1. Beatrice, L., Daya Antibakteri Ekstrak Buah Mahkota Dewa (Phaleria macrocarpa . Scheff ( Boerl.)) terhadap Enterococcus faecalis Sebagai Bahan Medikamen Saluran Akar Secara in Vitro, Universitas Sumatera Utara, 2010

2. Ingle., Bakland., Endodontics Fifth Edition, B C Decker Inc, Canada, 764, 2002

3. Soedjono, Patrick., Mooduto, Latief., dan Setyowati, Laksmiari., , Penutupan Apeks pada Pengisian Saluran Akar dengan Bahan Kalsium Oksida Lebih Baik dibanding Kalsium Hidroksida, Jurnal Persatuan Dokter Gigi Indonesia, Vol. 58 , No. 2, hal. 1-5, 2009

4. Kavitha R., Clinical and Radiographic Evaluation of Pulpectomies Using Zinc Oxide Eugenol with lodoform, Calcium Hydroxide with lodoform, Zinc Oxide Eugenol and Calcium Hydroxide with lodoform an Invivo Study, The Tamilnadu Dr. M. G. R. Medical University, 2005

5. Ranade MP and Kamra AI, A Comparative Tissue Toxicity Evaluation of Four Endodontic Materials, Endodontology, Vol. 15, 2003

6. Tigor, A., Nuryanti, A., Nur, A., Pengaruh Ekstrak Propolis Lebah Apis mellifera terhadap Diameter Zona Radikal Candida albicans (kajian in vitro), MIKGI, Vol 10, No 1, 2008
7. Challem, Jack., 1996, Medical Journals Document Value of Bee Propolis, Honey and Royal Jelly, dikutip pada tanggal 7 Februari 2011. Available fromwww.thenutritionreporter.com/ bee_stuff.htm

8. Parolia, Abhishek., Thomas, Manuel S., M. Kundabala and Mandakini Mohan., , Propolis and its potential uses in oral health, International Journal of Medicine and Medical Sciences, July, Vol. 2(7) pp. 210-215, 2010

9. Al-Shaher, Abdul et al., Effect of Propolis on Human Fibroblast from the Pulp and Periodontal Ligament, Journal of Endodontics, Vol.30 No. 5, 359-361, 2004

10. Gattuso, G., Barreca, D., Gargiulli, C., Leuzzi, U., Caristi, C., Flavonoid Composition of Citrus Juices, Molecules, 12, 1641-1673, 2007

11. Jawetz, E. J. L. Melnick and E. A. Adelberg., Mikrobiologi Kedokteran, Edisi 20, EGC, Jakarta, 1996

12. Awawdeh et al., Effectiveness of Propolis and Calcium Hydroxide as a Short-term Intracanal Medicament against Enterococcus faecalis: A laboratory study, Journal compilation Australian Society of Endodontology, 2008

13. Susanti, Ari., cit Schlegel, 1993, Daya antibakteri ekstrak etanol daun beluntas (Pluchea indica less) terhadap Escherichia coli secara in vitro Antibacterial activity of the ethanol extract Pluchea indica less leaves against Escherichia coli by in vitro, Journal Unair, Kedokteran Hewan Universitas Airlangga, 2011 